\title{
THE SEVENTH INTERNATIONAL WORKSHOP - 2018 "CONSTRUCTIVE METHODS FOR NON-LINEAR BOUNDARY VALUE PROBLEMS"
}

\author{
MIKLÓS RONTÓ \\ Received 02 October, 2018
}

In the period from 5 July to 8 July, 2018, the Seventh International Workshop2018 Constructive Methods for Non-Linear Boundary Value Problems had taken place in Miskolc, Hungary. The list of participants and the program can be found on the workshop web site:

\section{http: //mat76.mat.uni-miskolc . hu/bvpworkshop/about}

The workshop was organized by the Institute of Mathematics of the University of Miskolc and Institute of Mathematics of the Academy of Sciences of Czech Republic in cooperation with the Regional Committee of the Hungarian Academy of Sciences in Miskolc and Junior Mathematical Society in Miskolc.

The scope of the conference covered various topics related to the modern theory of boundary value problems in a broad sense, including initial value and periodic problems for functional differential equations, differential variational inequalities, certain singular problems, the method of lower and upper functions, stability, limit cycles, problems with state-dependent impulses, positive solutions of boundary value problems, oscillation theory, theory of abstract Kurzweil-Stieltjes integrals, differential-algebraic systems, vector valued metric approach in the theory of differential equations and inclusions, boundary value problems with integral and nonlocal conditions, asymptotic decomposition, numerical-analytic methods for boundary value problems, discontinuous differential equations with delayed and advanced arguments, equations with $p$-Laplacian.

The workshop was attended by more than 55 researchers from Austria, Brazil, Chile, Czech Republic, Georgia, Israel, Mexico, Poland, Romania, Russia, Ukraine, and Hungary, who held 20 and 30-minute lectures.

The Organizing and Program Committee of the workshop consisting of I. Astashova (Russia), J. Diblík (Czech Republic), A. Domoshnitsky (Israel), R. Hakl (Czech Republic), I. Kiguradze (Georgia), P. Körtesi (Hungary), N. Partsvania (Georgia), M. Perestyuk (Ukraine), N. Pop (Romania) I. Rachůnková (Czech Republic), A. Rontó (Czech Republic), A. Samoilenko (Ukraine), I. Szántó (Chile), J. Szigeti (Hungary), M. Tvrdý (Czech Republic), I. Piller (Hungary) and the author of this 
note (chairman) gratefully acknowledges the financial support provided by the following funds and institutions:

- Institute of Mathematics, University of Miskolc

- Faculty of Mechanical Engineering and Informatics, University of Miskolc

- Tudomány Támogatásáért Észak-Magyarországon Alapítvány.

This meeting was a continuation of the sixt previous workshops held in Miskolc in 2000, 2003 and 2015 [4], in Sárospatak in 2006 [1], in Eger in 2009 [2], and in Tokaj in 2012 [3].

We believe that the workshop has been successful and hope that the fruitful tradition of this kind of "compact" international meetings oriented at exchange of ideas of researchers working in closely related fields will continue in future.

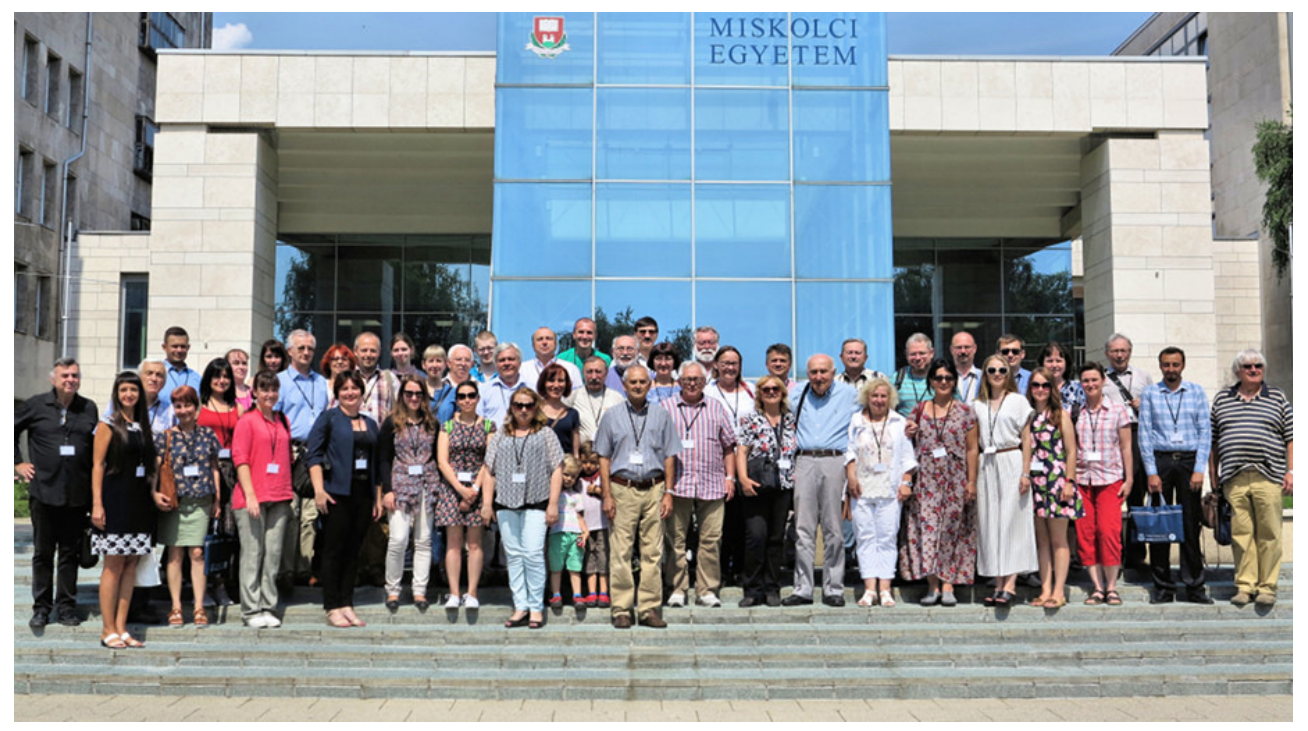

FIGURE 1. The participants of the workshop in front of the university main building

\section{REFERENCES}

[1] M. Rontó, "The third international workshop - 2006 "Constructive Methods for Non-Linear Boundary Value Problems"," Miskolc Math. Notes, vol. 7, no. 2, pp. 169-170, 2006, held in Sárospatak, June 7-10, 2006.

[2] M. Rontó, "The fourth international workshop - 2012 "Constructive Methods for Non-Linear Boundary Value Problems"," Miskolc Math. Notes, vol. 10, no. 2, pp. 223-224, 2009, held in Eger, July 1-4, 2009.

[3] M. Rontó, "The fifth international workshop - 2012 "Constructive Methods for Non-Linear Boundary Value Problems"," Miskolc Math. Notes, vol. 13, no. 2, pp. 483-484, 2012, held in Tokaj, June 28-July 1, 2012. 
[4] M. Rontó, "The sixth international workshop - 2015 "Constructive Methods for Non-Linear Boundary Value Problems"," Miskolc Math. Notes, vol. 16, no. 1, pp. 439-441, 2015, held in Miskolc, July 9-12, 2015.

\section{Author's address}

\section{Miklós Rontó}

Department of Analysis, University of Miskolc, 3515 Miskolc-Egyetemváros, Hungary

E-mail address: matronto@uni-miskolc.hu 